\title{
Characteristic properties of the genesis of Alnus incana (L.) Moench. associations in the south of Western Siberia
}

\author{
Boris Kharitontcev ${ }^{1}$, Elena Popova ${ }^{1 *}$ \\ ${ }^{1}$ Tobolsk complex scientific station UrB RAS, 16, Osipova, St., 626150, Tobolsk, Tyumen region, \\ Russia
}

\begin{abstract}
The associations formed by Alnus incana (L.) Moench. in the south of Western Siberia are limited to the middle and lower reaches of the Irtysh river in the Tyumen region (Tobolsk district, Russia). The paper describes Alnetum pteridiosum, Alnetum urticosum, Alnetum equisetosum, Alnetum coricosum, Alnetum coricoso - equisetosum, Alnetum coricoso - oxalidosum, Alnetum curtico - equisetosum, Alnetum equisetoso - miliosum, Alnetum coricosa - stellariosum, Alnetum urtico - aegopodiosum, Alnetum urtico - stellariosum, Alnetum-cirsiosum, Alnetum cystopteriosum, Alnetum urtico - miliosum, Alnetum poo urticosum, Alnetum chrysospleniosum, Alnetum corydaliosum, Alnetum impatieno - urticosum and Alnetum stellariosum associations. In these associations, more than a hundred of species of higher plants grow. The species composition analysis showed that they are mesothermal and hydrophilic, the shrub layer is not typical for them, and the grass cover of alder forests is not uniform in origin. During the formation of Alnetum association they interact with taiga, birch and linden forests through mutual exchange of species, and also experience anthropogenic influences, accompanied by the penetration of synanthropic species.
\end{abstract}

\section{Introduction}

Formations of species of Alnus genus with cenoformers Alnus glutinosa (L.) Graeth. (black alder forests) and Alnus incana (L.) Moench. (gray alder forests) aroused a certain interest of botanists in connection with the problem of their origin [1,2]. An analysis of the species composition of the complex of the described associations Alnus incana showed their different genesis. Gray alder (Alnus incana) is a tree growing along the banks of rivers, moor edges, in meadows. Its range covers the northern part of Western Europe, the north of European Russia, and reaches the Trans-Urals with an eastern boundary of $75^{\circ} \mathrm{E}$ $[3,4]$. In the Kurgan region and in the north of the range in the Khanty-Mansiysk Okrug, Alnus incana is a companion species, however as a cenose former it forms gray alder forests, which are most fully represented in the Irtysh basin of the Tyumen region. The presence of the formed cenoses of Alnus incana described in the vicinity of Tobolsk is explained by two reasons. First, along the bedrock bank of the Irtysh river, there is an

\footnotetext{
* Corresponding author: Popova-3456@mail.ru
} 
outflow of groundwater with waterlogged soils that are optimal for Alnus incana as a cenose former. Second, the bedrock bank is cut by small rivers and streams with trough-like deep valleys, where the optimal temperature parameters for gray alder forests are preserved along the bottoms of such valleys. The aim of the study was a complete inventory of the species of Alnus incana associations in three dislocations of the Tobolsk region with an elucidation of their genesis.

\section{Material and methods}

Site coordinates were obtained using satellite images of the terrain from Google Earth Pro 7.3.3 in the World Geodetic System 1984 (WGS-84) format.

The Alnus incana associations studied were located in the vicinity of the city of Tobolsk and in the Tobolsk region (the village of Priirtyshsky, the village of Verkhniye Aremzyany). The choice of sites was determined not only by the presence of gray alder forests formed there, but also by their specific local features. Within the city of Tobolsk, gray alder forests are most saturated with anthropogenic synanthropic species; in the nearterrace floodplain, gray alder forests are enriched with species of black alder forests that migrated along the Irtysh floodplain; in the Aremzyanka River basin, they reflect the Pleistocene stage of their genesis. The description of the test sites was carried out visually according to the generally accepted method $[5,6]$, taking into account the configuration and length of the sites. Test plots were determined in three replicates with parameters $20 \times$ $20 \mathrm{~m}^{2}$. Descriptions were made during the growing season to clarify the change in aspects of the plots, the total projective cover (TPC) of the herbaceous layer in the association and the projective cover (PC) of dominants and subdominants were determined.

The names of associations were given according to the principle of binary nomenclature using the following endings: etum (for the dominant) and osum (for the subdominant). Latin names of species are given according to the identification guide $[7,8,9]$.

\section{Results}

The first complex of the associations studied, Alnus incana, was formed in the vicinity of Tobolsk in the floodplain of the Tyrkovka River. Coordinates (N 58.170582 ${ }^{\circ}$ E $68.281001^{\circ}$ ).

Alnetum pteridiosum is located along the left bank of the river. The association is fourlayered. In the first layer we found Urtica sondenii (Simmons) Avrorin ex Geltman, Filipendula ulmaria (L.) Maxim. In the second layer, Aegopodium podagraria L., Matteuccia struthiopteris (L.) Tod. (PC 70\%), and Impatiens noli-tangere L grow. In the third and fourth layers, Stellaria bungeana Fenzl (layer III) and Adoxa moschatellina L. (layer IV) grow.

Alnetum urticosum is formed along the right bank of the river. The association is fourlayered. The first layer is formed by Urtica sondenii (Simmons) Avrorin ex Geltman (PC 50\%). In the second layer, Equisetum fluviatile L., Dryopteris carthusiana (Vill.) H.P. Fuchs, and Impatiens noli-tangere L were found. A distinctive feature of this association is the massive growth of Stellaria bungeana Fenzl and Galeopsis speciosa L. The presence of the latter species indicates a significant anthropogenic influence on this association, where other synanthropes were also found - Stellaria media L., Plantago major L., Polygonum sp., Poa annnua L.

Alnetum equisetosum is formed along the slope towards the river. The shrub layer (PC $50 \%$ ) is represented by three species: Rosa acicularis L., Ribes spicatum E. Robson and Viburnum opulus L. In the first layer Pteridium aquilinum (L.) Kuhn, the predominant of 
the grass cover Equisetum hyemale L. (PC 60\%), Dryopteris carthusiana (Vill.) H.P. Fuchs and others grow. Impatiens noli-tangere L. and Aegopodium podagraria L. are occasionally found in the second layer. The presence of species typical for birch forests in the third layer, Carex macroura Meinsh. and Rubus saxatilis L., indicates that this formation replaced Betuletum coricosum. Adoxa moschatellina L. is abundant in the fourth layer.

Alnetum coricosum is located at the base of the bedrock river bank. The association incorporates a shrub layer comprised of Rosa acicularis L. and Ribes spicatum E. Robson (PC 5\%). Urtica angustifolia Fisch. ex Hornem. is rarely found in the first layer, while in the second, Aegopodium podagraria L. and Equisetum hyemale L. are more abundant. But the ecological conditions of the Alnetum coricosum association are formed by Carex macroura Meinsh. (PC 70\%). The soils in this ecotope are partially acidified, therefore Deschampsia cespitosa (L.) P. Beauv. grows here.

Alnetum coricoso - equisetosum is formed at the base of the bedrock river bank. The predominant of the herbage cover of the association - Carex macroura Meinsh. (PC 50\%)grows in the third layer, and the subdominant Equisetum hyemale L. (PC 15\%) grows in the second one. In addition, Geranium sylvaticum L., Aegopodium podagraria L., and Agrimonia pilosa Ledeb were found in the second layer. The first and fourth layers are represented by separate species. Urtica sondenii (Simmons) Avrorin ex Geltman (layer I) and Adoxa moschatellina L. (layer IV) rarely grow here.

Alnetum coricoso - oxalidosum was found along the gentle slope of the bedrock bank of the river. A shrub layer represented by Lonicera xylosteum L., Padus avium Mill., and Rosa acicularis L. (PC 20\%) develops in the association. The first layer is formed by Angelica sylvestris L., the second layer is represented by Vicia sepium L., Equisetum hyemale L., Equisetum sylvaticum L., and Agrimonia pilosa Ledeb. The growth of the herbage cover predominat, Carex macroura Meinsh, was acknowledged in the third layer (PC 30\%). The subdominant Oxalis acetosella L. (PC 25\%) is characteristic of the fourth layer.

Alnetum curtico - equisetosum is formed along the river bank with moist soils. The shrub layer (PC 15\%) is formed by Rubus idaeus L. and Lonicera xylosteum L. The herbage cover predominants are Urtica sondenii (Simmons) Avrorin ex Geltman (PC 30\%) - a plant of the first layer - and Equisetum hyemale L. (PC 15\%) - a plant of the second layer. It should be noted that the following ferns are quite frequent in the Alnetum curtico equisetosum association: Athyrium filix-femina (L.) Roth, Dryopteris carthusiana (Vill.) H.P. Fuchs and Dryopteris assimilis S.Walker. Milium effusum L. grows in the first layer, Impatiens noli-tangere L. and Deschampsia cespitosa (L.) P. Beauv. grow in the second one. The third layer includes Geum rivale L. (a rare species for the flora of the southern part of Western Siberia) and Stellaria bungeana Fenzl.

Alnetum equisetoso - miliosum is distributed on a gentle slope near the bedrock bank of the river. The shrub layer (PC 5\%) is formed by Rubus idaeus L. and Lonicera xylosteum L. Equisetum hyemale L. (PC 20\%) and Milium effusum L. grow in the first layer, while Aegopodium podagraria L. and Equisetum sylvaticum L. grow in the second layer. It should be noted that satellite species of birch (Carex macroura Meinsh., Stellaria holostea L., Fragaria vesca L.) and taiga forests (Oxalis acetosella L.) are frequent in this association.

Alnetum coricosa - stellariosum is formed at the base of the slope towards the river. The shrub layer is formed by only one species - Lonicera xylosteum L. (PC 5\%). The first layer is dominated by Milium effusum L., Aegopodium podagraria L., etc., the second one is dominated by Equisetum sylvaticum L. and Rubus saxatilis L. The third layer is dominated by Carex macroura Meinsh. (PC 30\%) and Stellaria holostea L. (PC 20\%). Typically, nemoral species are Glechoma hederacea L. and Fragaria vesca L. The only point of growth of Alnetum Hypopitys monotropa Crantz is noted here. 
The features of the Alnus incana formation in the vicinity of the city of Tobolsk make it possible to note the following general patterns. The shrub layer, typical for taiga, birch and aspen forests, is not typical for alder forests. The shrubs found here (Rosa acicularis L., Ribes spicatum E. Robson and Viburnum opulus L., Lonicera xylosteum L.) are species of other arboreal formations. The herbage cover in alder forests is not uniform in origin. If alder forests begin to replace birch or taiga forests when the soil is flooded by groundwater, then at the first stages the types of previous associations in them are preserved.

The herbage cover of gray alder forests in the vicinity of the city is not very diverse and is represented by tall grasses (Filipendula ulmaria (L.) Maxim., Urtica sondenii (Simmons) Avrorin ex Geltman etc.), midgrasses (Poa trivialis L., Impatiens noli-tangere L., Agrimonia pilosa Ledeb. etc.), and short grasses (Chrysosplenium sibiricum (Ser.ex DC.) A.P. Khokhr., Adoxa moschatellina L., Glechoma hederacea L. A prominent place in the formation of gray alder forests is occupied by the species of lime-tree forests Stellaria bungeana Fenzl and Aegopodium podagraria L. Oftentimes, in gray alder forests, the following ferns grow: Athyrium filix-femina (L.) Roth, Dryopteris filix-mas (L.) Schott, Dryopteris carthusiana (Vill.) H.P. Fuchs, Dryopteris assimilis S.Walker. The latter species was found only in gray alder forests in the vicinity of the city.

The second complex of gray alder forests under study is located in the vicinity of Priirtyshsky village of the Tobolsk district, Russia. Coordinates in the terrace near flood plain of the Irtysh River (N 58.178365', E $68.331458^{\circ}$ ). In the ecotope, the soils are waterlogged, and the gray alder forests, due to interaction with taiga and linden forests, are enriched with their species.

Alnetum urtico - aegopodiosum is formed at the bottom of the terrace slope towards the Irtysh River. The first layer is formed by Filipendula ulmaria (L.) Maxim., Cirsium oleraceum (L.) Scop., Urtica angustifolia Fisch. ex Hornem., the projective cover is $30 \%$. In the same layer, Anthriscus sylvestris (L.) Hoffm. and Angelica sylvestris L. were found. The second layer features Impatiens noli-tangere L., Equisetum hyemale L., Equisetum hyemale L. (PC 15\%), and Equisetum hyemale L. The third layer is characterized by Caltha palustris L., Thelypteris palustris Schott, and Lamium album L. Adoxa moschatellina L. is abundant in the fourth layer. The hops make it difficult to move through the association.

Alnetum urtico - stellariosum was found on the terrace near flood plain of the Irtysh River. This association is an example of tall-grass alder forests. The first layer is formed by Urtica sondenii (Simmons) Avrorin ex Geltman (PC 40\%), Cinna latifolia (Trev.) Griseb., Milium effusum L., Angelica decursiva (Miq.) Franch. \& Sav., Angelica sylvestris L. Angelica decursiva (Miq.) Franch. \& Sav. The species was found only in gray alder forests in the vicinity of the city. The second layer is represented by Equisetum fluviatile L. and Epilobium adenocaulon Hausskn. Poa remota Forsell and Lamium album L. are not uncommon in the third layer. Glechoma hederacea L. grows in the fourth layer. Lianas are represented by Humulus lupulus L. and Solanum kitagawae Schonb.-Tem.

Alnetum - cirsiosum is formed in the Irtysh floodplain. The association is the only one among gray alder forests due to the background of Carduus crispus L. in it. Urtica sondenii (Simmons) Avrorin ex Geltman, Barbarea stricta Andrz., and Cicuta virosa L. grow in the first layer. Impatiens noli-tangere L., Galeopsis speciosa Mill., and Galeopsis bifida Boenn. are found in the second layer. In the third layer Mentha arvensis L., Poa palustris L., and Stellaria longifolia H.L. Muhl. ex Willd. are found.

Alnetum - cirsiosum was studied on the terrace of a forest stream flowing into the dead channel of the Irtysh river. The association is unusual due to the massive growth of Cystopteris sudetica A. Brown \& Milde, a species listed in the Red Book of Tyumen Region. The first layer is formed by rare specimens of Urtica sondenii (Simmons) Avrorin ex Geltman and more frequent specimens of Equisetum hyemale L. Calamagrostis arundinacea (L.) Roth and Calamagrostis canescens (Weber) Roth are occasionally found 
here. In the second layer, Dryopteris carthusiana (Vill.) H.P. Fuchs. shrubs were found. In the third layer, along with the background-forming Cystopteris sudetica A. Brown \& Milde (PC 70\%), the small fern of Gymnocarpium dryopteris (L.) Newman grows.

The third complex of the studied associations, Alnus incana, is located in the basin of the Aremzyanka River, which flows in the north of the district and flows into the Irtysh River. Aremzyanka has a very deep trough-like valley, where gray alder forests are formed. Coordinates of the described plant communities (N 58.103565, E $68.724143^{\circ}$ ).

Alnetum urtico - miliosum is formed along a gentle slope from the bedrock right bank of the Aremzyanka River towards the floodplain. The first layer is represented by Urtica sondenii (Simmons) Avrorin ex Geltman (PC 40\%), Anthriscus sylvestris (L.) Hoffm., Aconitum septentrionale Koelle, Filipendula ulmaria (L.) Maxim. and others. In the second layer, Trollius europaeus L., Aegopodium podagraria L., Impatiens noli-tangere L., and Agrimonia eupatoria L were found. In the third layer, Stellaria bungeana Fenzl grows, in the fourth one - Chrysosplenium sibiricum (Ser.ex DC.) A.P. Khokhr., Oxalis acetosella L.

Alnetum poo - urticosum stretches along the stream flowing into Aremzyanka. The shrub layer is represented by Ribes nigrum L. (PC 5\%). The first layer is includes Filipendula ulmaria (L.) Maxim., Urtica sondenii (Simmons) Avrorin ex Geltman (PC 10\%), and Cinna latifolia (Trev.) Griseb. In some places Poa remota Forsell. forms the background (PC 20\%), along with Chrysosplenium sibiricum (Ser.ex DC.) A.P. Khokhr. (PC 5\%). In the second layer, Scirpus sylvaticus L., Dryopteris carthusiana (Vill.) H.P. Fuchs, and Galeopsis speciosa Mill. Were found. The third layer is formed by Chrysosplenium sibiricum (Ser.ex DC.) A.P. Khokhr. and Glechoma hederacea L.

Alnetum chrysospleniosum is developed along the gentle slope of the Aremzyanka floodplain. The association is four-layered. The shrub layer is formed by Swida alba (L.) Opiz (PC 10\%). In the first layer, Urtica sondenii (Simmons) Avrorin ex Geltman, Parasenecio hastatus (L.) H. Koyama, Aconitum septentrionale Koelle and others grow. The second layer features Matteuccia struthiopteris (L.) Tod., Dryopteris carthusiana (Vill.) H.P. Fuchs. The third layer features Aegopodium podagraria L. and Scirpus sylvaticus L. The fourth layer is composed of small grasses - Trientalis europaea L., Adoxa moschatellina L., Cystopteris fragilis (L.) Bernh, etc. A distinctive feature of the association is background formation by Chrysosplenium sibiricum (Ser. ex DC.) A.P. Khokhr. (PC 50\%).

Alnetum corydaliosum is formed along the gentle slope of the floodplain towards the channel. The area is well drained. A distinctive feature of the association is the spring blueand-violet aspect from the ephemeroids of Corydalis solidiformis Charit., with yellow spots of Ranunculus aggr. monophyllus. In the first layer, Anthriscus sylvestris (L.) Hoffm., Milium effusum L., Urtica sondenii (Simmons) Avrorin ex Geltman, and others are rarely found. Poa trivialis L. (layer III) and Chrysosplenium sibiricum (Ser. ex DC.) A.P. Khokhr. (layer IV) are abundant in this association. Less common are Matteuccia struthiopteris (L.) Tod. (the second layer) and Aegopodium podagraria L. (the third layer). The presence of Corydalis solidiformis allows classification of this association as specially protected.

Alnetum impatieno - urticosum on silt deposits in the Aremzyanka floodplain. The shrub layer is represented by Sambucus sibirica Nakai and Ribes spicatum E. Robson (PC 10\%). Phalaroides arundinacea (L) Rauschert, Urtica sondenii (Simmons) Avrorin ex Geltman (PC 15\%), and Angelica sylvestris L. are found in the first layer of the herbage cover. In the third layer, Lamium album L., Corydalis solidiformis, Lamium album L., Festuca rubra L. were found. The second layer includes the herbage cover predominant Impatiens noli-tangere L. (PC 30\%) and the rare species of Elymus sibiricus L. Chrysosplenium sibiricum (Ser. ex DC.) A.P. Khokhr and Carex elongata L. are abundant in the fourth layer. 
Alnetum stellariosum is described in the floodplain of the Aremzyanka River along the dead channel. In the first layer, Parasenecio hastatus (L.) H. Koyama, Urtica sondenii (Simmons) Avrorin ex Geltman, Calamagrostis langsdorffii (Link) Trin., Heracleum sibiricum L., and others were found. In the second layer, Elymus sibiricus L., Dryopteris filix-mas (L.) Schott, and Athyrium filix-femina (L.) Roth. are common. The third layer features Aegopodium podagraria L., Impatiens noli-tangere L., Stellaria bungeana Fenzl, etc. The fourth layer includes Glechoma hederacea L., Thelypteris palustris Schott, Carex elongata L., etc.

\section{Discussion}

In the vicinity of the city of Tobolsk, gray alder forests can appear in the place of birch forests, from which Carex macroura Meinsh., Stellaria holostea L., and others are left. Oxalis acetosella L., Pyrola species are the heritage of taiga forests in alder stands. In gray alder forest near the village of Priirtyshsky Huperzia selago subsp. selago was found, which is a species left from a pine forest, in the place of which the gray alder forest was formed. At the same time, there is a gradual decrease in the activity of the species of the previous taiga associations and an increase in the abundance and coverage of satellite species of alder forests. The first complex of associations of Alnus incana, located within the city limits, is characterized by the growth of the following synanthropic species: Galeopsis bifida Boenn., Galeopsis speciosa L., Stellaria media L., Plantago major L., Polygonum sp., Poa annnua L., Lamium album L., etc. Such set synanthropic species reflects the process of degradation of gray alder forests near residential areas.

The described associations of Alnus incana in the Irtysh floodplain make it possible to clarify the ecological features of gray alder forests. Considering the accompanying herbaceous satellites, they are mesothermal (Cystopteris sudetica A. Brown \& Milde, Carduus crispus L., Humulus lupulus L., Solanum kitagawae Schonb.-Tem.) and hygrophilic (Caltha palustris L. and Impatiens noli-tangere L.). Cinna latifolia (Trev.) Griseb., Stellaria longifolia H.L. Muhl. ex Willd.), and Poa remota Forsell. are important species for the genesis of gray alder forests. It is likely that these species are the legacy of the coexisting taiga/gray alder complex in the preglacial time. Over the floodplain of the Irtysh River, there was an exchange, possibly through the floodplain of the Tobol River, between gray alder forests and the black alder forests currently located in this area.

The gray alder forest in the Aremzyanka River floodplain includes species of various complexes: typically, forest (taiga) species (Chrysosplenium sibiricum (Ser.ex DC.) A.P. Khokhr., Elymus sibiricus L., Swida alba (L.) Opiz, etc.); tiletus (Tilia L.) complex species (Stellaria bungeana Fenzl, Dryopteris filix-mas (L.) Schott, Dryopteris affinis (Lowe) Fraser-Jenk. etc.); swamp-meadow-forest species (Thelypteris palustris Schott, Caltha palustris L. etc.); meadow-and-forest species (Filipendula ulmaria (L.) Maxim., Calamagrostis langsdorffii (Link) Trin., Calamagrostis canescens (Weber) Roth and others). Such a complex phytoecological composition of gray alder stands reflects the multistage formation, which is confirmed by their comparison with the most fully formed alder forests of Primorye.

Many researchers believe that black alder forests have initial generative relations with the tropical lowland forests of Eurasia, while gray alder forests were originally formed in the mountain ranges of Central Asia (Alnus incana areal). This is confirmed by the fact that up to the present time many herbaceous satellites of gray alder forests grow in the mountains along with the plains. At this time, gray alder forests were common in a much larger area and were displaced to the north in comparison to their present-day coenoareal (the areal of Solanum kitagawae Schonbeck / Temesy, a satellite of gray alder forrests) [10, $11,12,13]$. 
Places of genesis of association complexes of Alnus incana (L.) Moench. and Alnus glutinosa (L.) Graeth. are outlined by the areals of the correct species of these complexes Urtica galeopsigolia Wierzb. Ex Opiz. (Europe, Caucasus) and Urtica sondenii (Simmons) Avrorin ex Geltman, (Northern Europe, Siberia, Northwest Mongolia). At this time, fluctuations in the boundaries of plant zones in Eurasia occur due to the migrations of species and the formation of specific complexes of biota. These include gray alder forests, in which endemics are formed (Corydalis solidiformis, etc.) and enriched with species of taiga, birch and even linden forests.

\section{Conclusion}

Based on the species composition analysis of Alnus incana associations, the following species can be attributed to the gray alder forest complex: Impatiens noli-tangere L., Urtica sondenii (Simmons) Avrorin ex Geltman, Chrysosplenium sibiricum (Ser. ex DC.) A.P. Khokhr., Glechoma hederacea L., Carex elongata L., Lamium album L., Thelypteris palustris Schott, Cirsium oleraceum (L.) Scop., Cinna latifolia (Trev.) Griseb., Sambucus sibirica Nakai, Caltha palustris L., Stellaria longifolia H.L. Muhl. ex Willd., Galeopsis speciosa Mill., Archangelica decurrens Ledeb., and Corydalis solidiformis Charit.

The peculiarities of the genesis of the complex of Alnus incana associations can be clarified by comparing the species composition of the complex of black alder forests, which makes it possible to clarify certain aspects of their origin. First, the participation of boreal species of Cinna latifolia (Trev.) Griseb., Stellaria longifolia H.L. Muhl. ex Willd.) increases in gray alder forests in comparison to black alder forests. Second, in the gray alder forests of the Tobolsk region, the growth of the endemic species of Corydalis solidiformis, characteristic of this complex, was noted. Third, black alder species (Solanum dulcamara L., Carex elongata L., etc.) grow in the gray alder forests described in this paper. No growth of the Alnus incana complex species was registered in black alder forests.

\section{References}

1. M. Veličković, T. Savić, Plant Biosystems - An International Journal Dealing with all Aspects of Plant Biology 144 (3), 692-702 (2010)

2. J.R. Milligan, R.A. Krebs, K.M. Tarun, International Journal of Plant Sciences 169(5), 625-630 (2008)

3. L. Kullman, Journal of Ecology 86(2), 421-428 (1998)

4. W. Bertoldi, A. Gurnell, River Res Applic 36(7), 1183-1201 (2020)

5. P.V. Kulikov, Identifier of vascular plants of the Chelyabinsk region (UrB RAS, Ekaterinburg, 2010)

6. S.K. Cherepanov, Journal of Environmental Quality 31(1), 350-357 (2002)

7. N.I. Naumenko, Flora and vegetation of the southern Zuraliy (Kurgan University, Kurgan, 2004)

8. H. Krause, K. Culmsee, C. Wesche Leuschner, Folia Geobotanica 50(3), 253-266 (2015)

9. A. Bykov, Ecological dictionary (Science, Alma-Ata, 1983)

10. L.V. Shumilova, Botanical geography of Siberia (Publishing house of Tomsk University, Tomsk, 1962)

11. J.M. Arenas, A. Escudero, I. Mola, M.A. Casado, Applied Vegetation Science 20(4), 527-537 (2017) 
12. D. Jewitt, P.S. Goodman, B.F.N. Erasmus, T.G. O'Connor, T.F. Witkowski, Environmental Management 5(5), 792-806 (2017)

13. L. Kütt, T. Paal, K. Lõhmus, I. Rammi, Kr. Zobel, J. Liira, Applied Vegetation Science 21(3), 363-372 (2018)

14. P.M. Tikka, P.S. Koski, R.A. Kivelä, M.T. Kuitunen, Applied Vegetation Science 3, 25-32 (2000) 